\title{
Fast, non-toxic, and inexpensive n-butanol preparation of recombinant plasmids
}

\author{
Jürgen Brieger, Eberhard J. Weidt and Jochen Decker
}

\begin{abstract} cent per plasmid preparation.

\section{INTRODUCTION}

Recombinant plasmid isolation is an essential method in molecular genetics. Various satisfactory procedures for plasmid preparation have been described (Sambrook et al., 1989; Ausubel et al., 1997). However, most protocols require alkali or enzymatic lysis, special equipment like vacuum devices, expensive kits, toxic chemicals or considerable hands-on time. Here we report an easy-to-perform, inexpensive, rapid, non-toxic and efficient method for high throughput plasmid isolation. We introduce a simple, but essential modification to the procedure initially described by Mak et al. (1991). Plasmid DNA yield recovered by each preparation using the original n-butanol protocol in our experience was very low. By doubling homogenization time, yield increases, but number of processable samples is limited. To overcome this limitation we added glass beads to cell suspension prior to homogenization, thus achieving rapid lysis and enhancing both sample throughput and plasmid yield.
\end{abstract}

Various commercial and non-commercial plasmid preparation protocols are currently available. However, the kits are expensive and many of the protocols contain toxic chemicals. Here we present a novel, optimized and, therefore, very advantageous plasmid preparation protocol using n-butanol. The preparation can be performed quickly and no toxic chemicals are used, at overall costs of about one

\section{METHOD}

First, $0.5 \mathrm{ml}$ saturated overnight $E$. coli culture, $1 \mathrm{ml}$ n-butanol and $50 \mathrm{mg}$ acid-washed glass beads $(425-600 \mu$, Sigma, Deisenhofen, FRG) were homogenized for $20 \mathrm{~s}$ by vigorous mixing and subsequently spun for $1 \mathrm{~min}$ at 14,000 $g$ using a conventional tabletop centrifuge. The aqueous, lower phase was then transferred to another tube and the plasmid DNA directly precipitated with 0.8 Vol isopropanol. After washing twice with $70 \% \mathrm{EtOH}$, the DNA was dissolved in $10 \mu \mathrm{l} \mathrm{H}_{2} \mathrm{O}$. Yield was about 1-2 $\mu \mathrm{g}$ plasmid DNA per sample. Bacterial RNA was eliminated by adding RNAse prior to subsequent restriction analysis.

\section{RESULTS}

Using the method described above, 20 samples were easily prepared in $30 \mathrm{~min}$, a yield of about four times the plasmid DNA [1-2] obtained by the original protocol and enough for subsequent experiments. The DNA is suitable for subcloning procedures, PCR or restriction analysis. Costs for chemicals per sample preparation are about one cent. We therefore recommend this method as an extremely inexpensive alternative for high throughput screenings.

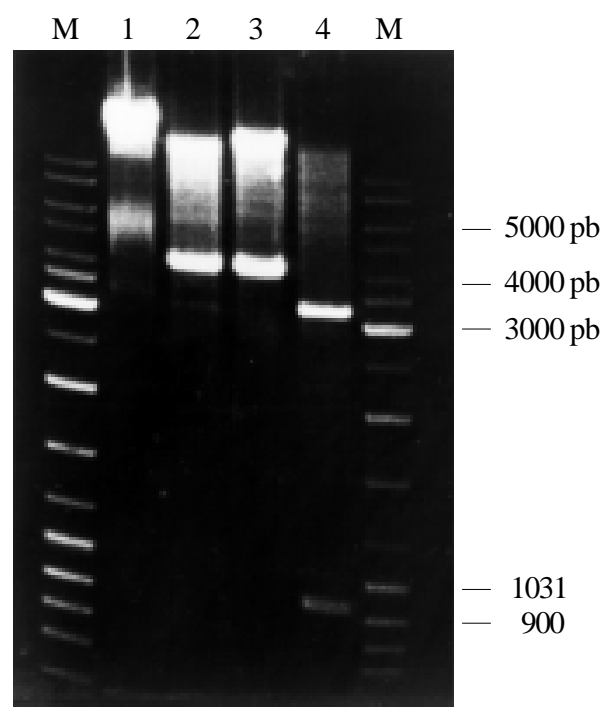

Figure 1 - Agarose gel electrophoresis of restricted recombinant plasmids. One representative colony Xl 1-blue transformed with pcDNA3-VHL was cultured in LB-medium overnight and plasmids were recovered as described above. Restriction was performed using $1 \mu \mathrm{l}(\approx 200 \mathrm{ng})$ plasmid DNA, and 10 $\mathrm{U}$ enzyme, each, for $1 \mathrm{~h}$ at $37^{\circ} \mathrm{C}$ in a final volume of $10 \mu \mathrm{l}$, and then subjected to electrophoresis. M, Gene Ruler ${ }^{\mathrm{TM}}$-DNA Ladder (MBI Fermentas, St. LeonRot, Germany). Lane 1, Unrestricted DNA; lane 2, EcoR1 restricted DNA; lane 3, BamH1 restricted DNA; lane 4, EcoR1/BamH1 restricted DNA. 


\section{RESUMO}

Atualmente vários protocolos comerciais e não comerciais para preparação de plasmídeos estão disponíveis. Contudo, os kits são caros e muitos dos protocolos contêm substâncias químicas tóxicas. Apresentamos neste trabalho um novo, otimizado e portanto muito vantajoso protocolo para preparação de plasmídios usando n-butanol. A preparação pode ser efetuada rapidamente, sem adição de substâncias químicas tóxicas e a um custo total de aproximadamente um centavo (americano) por preparação.

\section{REFERENCES}

Ausubel, F.M., Brent, R., Kingston, R.E., Moore, D.D., Seidmen, Z.G., Smith, Z.A. and Skuhl, L.X. (1997). Current Protocols in Molecular Biology. John Wiley \& Sons, New York, NY.

Mak, Y.M., Sornarajah, R. and Ho, K.K. (1991). A rapit procedure for detecting recombinant plasmids using butanol extraction. BioTechniques 11: 723 .

Sambrook, J., Fritsch, E.F. and Maniatis, T. (1989). Molecular Cloning: A Laboratory Manual. 2nd edn. Cold Spring Harbor Laboratory Press, Cold Spring Harbor, NY.

(Received November 29, 1999) 